\title{
Ernst Neufert's 'Lebensgestaltungslehre': formatting life beyond the built
}

\author{
Anna-Maria Meister* \\ Professor of Architecture Theory and Science, Department of Architecture, Technical University of \\ Darmstadt \\ *Email: meister@atw.tu-darmstadt.de
}

\begin{abstract}
In 1936, the Bauhaus-trained architect Ernst Neufert published the first edition of his seminal book Bau-Entwurfslehre. One of the most successful architecture books to date, the encyclopedic volume offered dimensioned floor plans for architectural tasks ranging from bunkers to dog kennels to Zeppelins. Two years later, Neufert started working as 'norm expert' for Reichsminister Albert Speer, with whom he published another manual in 1943, Bauordnungslehre. Meant to provide a total system of measures for architecture at large, the volume subjected building blocks, bricks and human bodies to Neufert's all-encompassing octametric system. This article contrasts these two books against Neufert's unpublished treatise - 'Lebensgestaltungslehre'. Never a bound volume, the latter was sketched out in diary entries between 1936 and 1942 on folded DIN A4 sheets (themselves normed) and organized in a card index. Reading them across their medial states, this article investigates the material, methodological and ideological character of Neufert's Lehren. This is not the story of a handbook; rather, this is a story of constructing Lehre one sheet at a time. Neufert's attempt to format German society in the 1930s and 1940s through inherently architectural means such as floor plans, norms and a system of measures ultimately shaped the designing subject - starting with himself.
\end{abstract}

When an architect in Germany designs a building, chances are that she will reach for 'the Neufert' at some point. ${ }^{1}$ Now in its forty-second German edition with eighteen international editions, Ernst Neufert's (1900-86) eponymous Bau-Entwurfslehre (BEL), first published in 1936, comprises an encyclopedic assortment of floor-plan elements that still serves as a reference for the organization of competition briefs and the execution of commissioned buildings. With its collection of 'solutions' for architectural programmes for everything from dog kennels and Zeppelins to office buildings and school layouts the volume has arguably educated more of Germany's architects and shaped more of its architectural production than any architectural school or famous master. ${ }^{2}$

1 Ernst Neufert, Bau-Entwurfslehre: Grundlagen, Normen und Vorschriften über Anlage, Bau, Gestaltung, Raumbedarf, Raumbeziehungen. Maße für Gebäude, Räume, Einrichtungen und Geräte mit dem Menschen als Maß und Ziel, Berlin: Bauwelt-Verlag, 1936. A revised edition first appeared in English as Architects' Data: The Handbook of Building Types, London: Lockwood, 1970.

2 Gernot Weckherlin discusses Neufert's far-reaching impact in his book on the BEL. See Gernot Weckherlin, BEL: Zur Systematik des architektonischen Wissens am Beispiel von Ernst Neuferts 'Bauentwurfslehre', Berlin: E. Wasmuth, 2017, pp. 10-15.

(C) The Author(s), 2020. Published by Cambridge University Press on behalf of British Society for the History of Science. This is an Open Access article, distributed under the terms of the Creative Commons Attribution-NonCommercial-NoDerivatives licence (http://creativecommons.org/licenses/by-nc-nd/4.0/), which permits non-commercial re-use, distribution, and reproduction in any medium, provided the original work is unaltered and is properly cited. The written permission of Cambridge University Press must be obtained for commercial re-use or in order to create a derivative work. 
Educated by the first Bauhaus director Walter Gropius (1883-1969), the BEL soon established Neufert as the German expert for technical norms in architecture, as it compiled standardized building regulations and pre-planned elements of all scales for ready-at-hand usage. The BEL had comprehensive aspirations: it provided schemes for different scales of building, and offered overviews of diverse typologies - all measured, rasterized and broken down from street width to office floor plans to the typewriter on the desk. But it also instructed architects how to draw or hold a pencil, and prescribed the spatial dimensions for all activities in the household. In short, through this manual, Neufert tried to define all elements of architectural production - including 'man's measures and spatial needs'. Hired in 1938 by Reichsminister Albert Speer (1905-81) as standardization expert, ${ }^{3}$ Neufert set out to conceptualize a total system of measurements for the entire German building industry, motivated by his 'daily experience of lacking a super-ordinated relation of measure of parts to each other, which would have made their understanding and assembly easier'. In 1943, this system was published in Neufert's Bauordnungslehre ('Building Order Treatise', BOL, a compendium of norms for the building industry): his second manual. ${ }^{5}$ This work on behalf of the National Socialist regime (with a foreword by Albert Speer citing Adolf Hitler) was the architects' tool Neufert had deemed missing not only for the construction of a state-controlled built environment, but for architecture at large - especially in light of the ever-growing number of building standards issued by a private association of engineers, architects and industry representatives, the German Institute for Norms (DIN, founded in 1917). ${ }^{6}$

While conventionally translated in histories of technology and architecture as 'standard', it is important to this history to note that the German term Norm is suspended between technical regulation and social mode of conduct. The norm, and 'to norm', in twentieth-century Germany, were acts of deliberate form-giving with far-reaching intentions to reshape society. The German Institute for Norms (DIN), founded in 1917 under the name Normenausschuß der deutschen Industrie as an initiative of the military Fabrikationsbüro (Office for Production, FABO) to streamline the production of weapons and munitions, broadened its ambitions soon after the First World War beyond military production. By 1926, the committee changed its name accordingly and dropped the Industrie from its name, announcing its total scope as Deutscher Normenausschuß (German Norm Committee): thousands of DIN norms now regulated German building production and household items from doorknobs to postcards. ${ }^{7}$ Scaled up (and down), the military origins of efficiency and control were taken up by engineers to construct a safe post-First World War German state. Modern architects such as Gropius took the total ambition of the DIN to heart and saw in the norm's principle the opportunity for

3 Neufert, Bau-Entwurfslehre, op. cit. (1), p. 30.

4 Neufert, Bau-Entwurfslehre, op. cit. (1), p. 10.

5 Ernst Neufert, Bauordnungslehre, Berlin: Volk und Reich Verlag, 1943.

6 After its founding 1917 as Normenausschuß der deutschen Industrie, this committee was in 1926 named Deutscher Normenausschuß (DNA) and only later renamed Deutsches Institut für Normung (DIN). The latter is the far-better-known denomination and hence used throughout this piece. Conventionally Norm is translated into English as 'standard' for the name of the organization, but as I explain in this article, the association with 'norm' is crucial. For a history of the shared project of DIN agents and modern architects see Anna-Maria Meister, 'From form to norm: systems and values in German design circa 1922, 1936, 1953', PhD dissertation, Princeton University, 2018. For an institutional history of the DIN institute see Günther Luxbacher, DIN von 1917 bis 2017 : Normung zwischen Konsens und Konkurrenz im Interesse der technisch-wirtschaftlichen Entwicklung, Berlin: Beuth Verlag, 2017; and Thomas Wölker, Entstehung und Entwicklung des deutschen Normenausschusses 1917 bis 1925, Berlin: Beuth Verlag, 1992.

7 For an insightful analysis of the norm effort in military and weaponry see Peter Berz, 08/15: ein Standard des 20. Jahrhunderts, Munich: Fink, 2001. 
the design of a new social order. Neufert, his student, would soon take modern architecture's will to order beyond architecture - to the subject.

Neufert's published manuals are garnering increasing scholarly attention, both for their widespread impact on architectural production (hitherto mostly analysed through the influences of the so-called avant-gardes), and, more recently, for their charged political implications which have surfaced after long-standing assumptions of standardization as technology supposedly free of ideology. ${ }^{8}$ Exploiting this assumed neutrality, standardization efforts for the building industry proved a resilient platform for changing political ideologies in three different political systems in twentieth-century Germany, since, as architecture historian Nader Vossoughian has shown, 'technical standards also serve a normalizing function' in society. ${ }^{9}$ Claiming repeatedly that 'technology has nothing to do with politics', ${ }^{10}$ Neufert profited directly from such perceived lack of political or aesthetic intention behind norm making and standardization, as his continuous career as teacher, architect and author through different political regimes demonstrates: he was the first full professor reinstated at a German university after the end of the Second World War, despite having worked directly under Speer, Hitler's architect and master strategist. For Neufert, his books were the necessary tool to prepare architects for the materialized totality of norms that the DIN had envisioned: an ordered life, furnished with normed objects, lived within standardized houses. Neufert's ambition, indebted both to the total aspirations of modern architecture and to his technocratic, indiscriminate methodology, made his work all the more suitable for the total instrumentalization of aesthetics for politics by the National Socialist regime.

It is therefore imperative to expand the scope of analysis of Neufert's architecture manuals, in which he ostensibly aimed to order not just the built environment, but also the people living in it. To break open readings of Neufert's books as pragmatic instructions for architects, this article focuses on Neufert's third, unpublished, treatise: his 'Lebensgestaltungslehre', or 'Life design manual'. While both BEL and BOL were published as bound volumes, the unknown treatise 'Lebensgestaltungslehre' is not a book not even a manuscript. Rather, it consists of a series of diary entries on folded paper sheets, an order mechanism, and a plan for future publication (Figure 1). ${ }^{11}$ And yet for Neufert himself it was a central piece of his oeuvre, the missing piece to bridge the scale from building to life, by organizing and ordering his mind with the same technique and rigour as his architecture. Despite the deceiving appearance (after all, it never became a book), this planned manual, too, bears the label Lehre, and this manual, too, followed Neufert's work process developed in his years of teaching and writing.

The BEL - the famous, published manual - had not emerged as conventional manuscript, but started out as a set of single-sheet publications in the architecture periodical Bauwelt, sorted according to categories not unlike the diary. These single sheets, called 'Bauwelt-Tafeln', were announced in 1935 as 'something totally different' from a book, presented in 'mostly serialized depictions' as a 'time lapse' (Zeitraffer) mechanism

8 The first and in many regards still essential theoretical discusssion on Neufert and his work is Walter Prigge (ed.), Ernst Neufert: Normierte Baukultur im 20. Jahrhundert, Frankfurt am Main: Campus, 1999. More recently see Weckherlin, op. cit. (2), for a discussion of Neufert's work and teaching in depth beyond the BEL; and Nader Vossoughian, 'Standardization reconsidered: Normierung in and after Ernst Neufert's Bauentwurfslehre (1936)', Grey Room (2014) 54, pp. 35-56.

9 Vossoughian, op. cit. (8), 35, original emphasis.

10 See Neufert's Statement for his de-Nazification, Ernst Neufert papers, Archiv der Moderne, Bauhaus-Universität Weimar: 'weil Technik nichts mit Politik zu tun hat'.

11 See Ernst Neufert's diary index in the Ernst Neufert papers, Archiv der Moderne, Bauhaus-Universität Weimar. When I first studied this source in 2013, it had only recently been acquired, was still in the original index card box and not yet archivally filed and stored. 


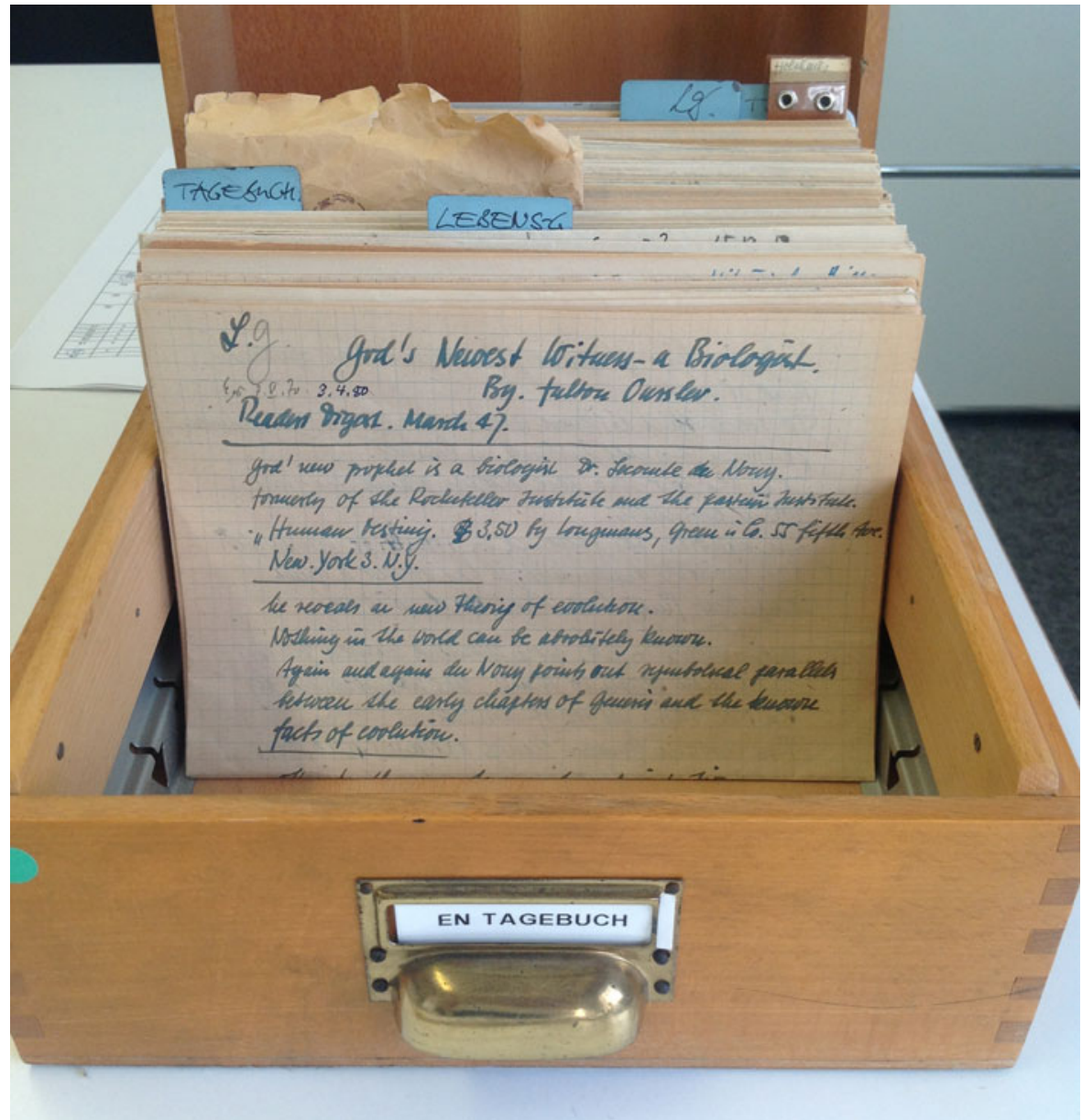

Figure I. Ernst Neufert's diary in its original state as card index. Archiv der Moderne, Bauhaus-Universität Weimar. Photograph by the author.

(Figure 2). These depictions were based in turn on Neufert's teaching methods that he had developed at the Bauhochschule Weimar under Otto Bartning's directorship, ${ }^{12}$ where he taught, starting in 1926 (at a mere twenty-six years old), a course called Rapid Design (Schnellentwerfen). ${ }^{13}$ Presented with concise, programmatically specific briefs, the students were tasked to come up with a functional design solution within mere hours, submitted on DIN A paper sheets. ${ }^{14}$ Neufert, in turn, would file the student's drawings sorted according to programme, creating a 'standard index' (Standardkartei) of

12 See 'Eine Entwurfslehre in Bilderreihen', in Bauwelt (1935) 14, p. 321. When Neufert mentions his initial work on the matter in the introduction to the first BEL, he speaks about roughly ten years that he had dealt with that material, and in a later edition he deliberately corrected the 'roughly ten years' to the date 1926, the year he started teaching at the Bauhochschule. Corrections made for the seventeenth edition of the BEL, Ernst Neufert Archiv, TU Darmstadt.

13 Weckherlin, op. cit. (2), pp. 109-22.

14 See Otto Bartning, Staatliche Bauhochschule Weimar: Aufbau und Ziel, Weimar: Verlag Staatliche Bauhochschule, 1927, p. 8; and Prigge, op. cit. (8), p. 9. On the Schnellentwerfen as method and base for the BEL see Gernot Weckherlin, 'Ernst Neufert's Architects' Data: anxiety, creativity and authorial abdication', in Tim 

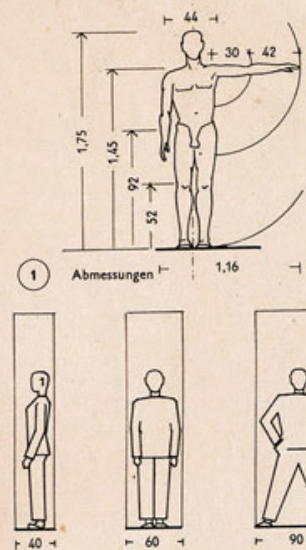
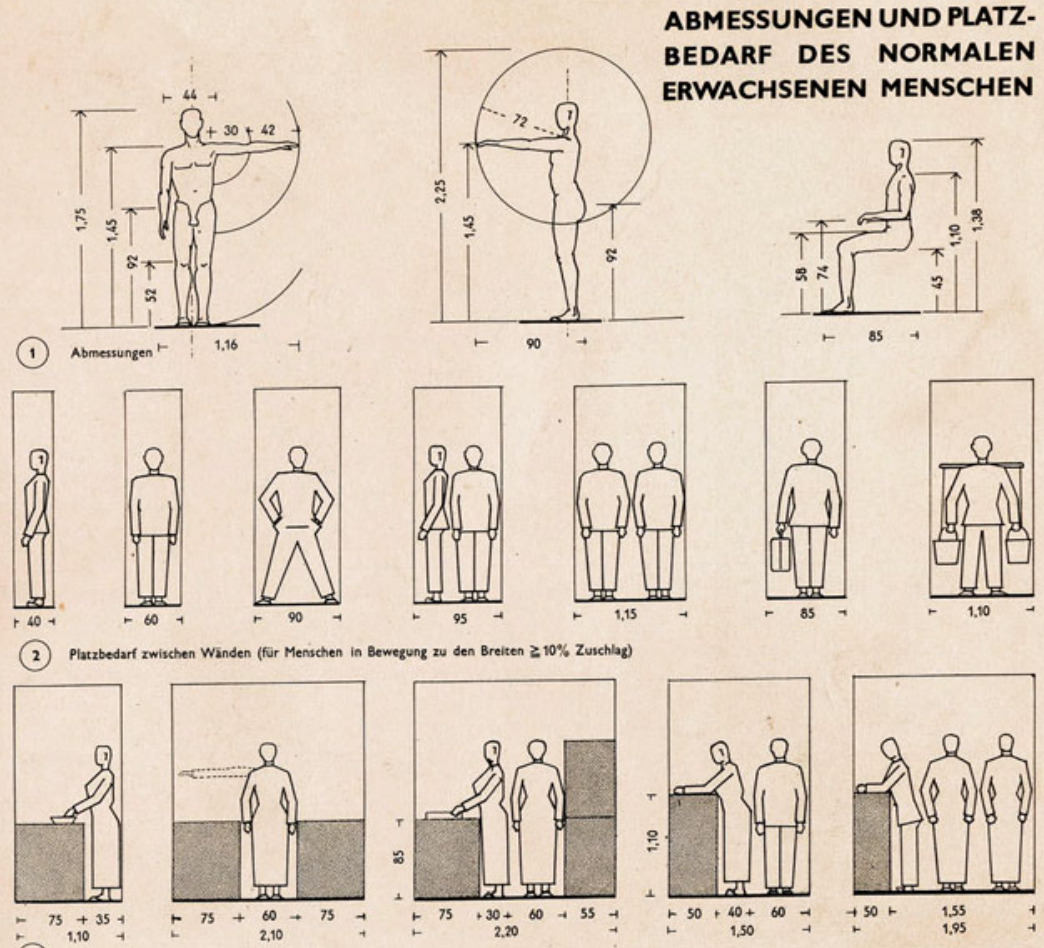

(3) Plazzbedarf zwischen Möbeln

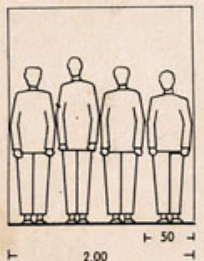

(4) Platzbedari von Gruppen
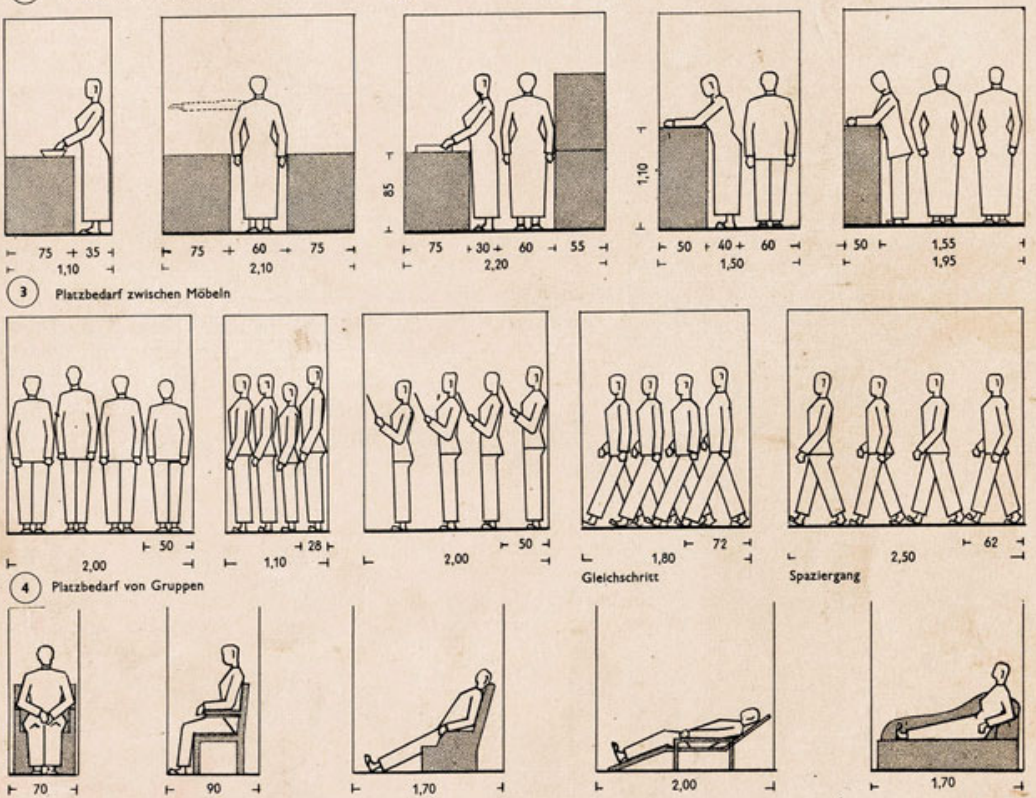

(5) Platzbedarf mit Mobeln
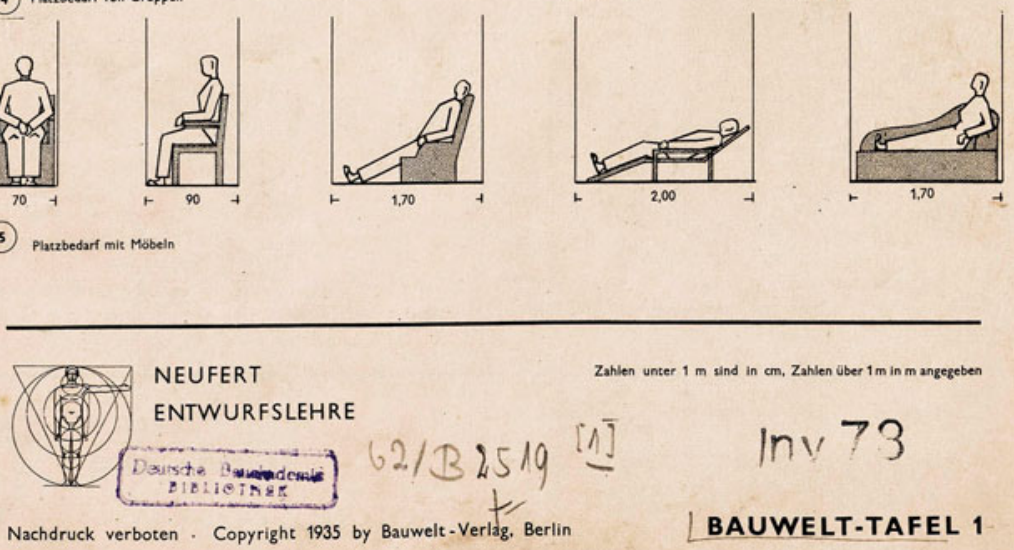

Figure 2. Ernst Neufert's 'Bauwelt-Tafel I' configured human bodies into 'measures and spatial needs of the normal adult human' based on DIN A paper formats. Insert in Bauwelt, Bauwelt-Verlag, 1935. 
architectural proposals for each brief - the index that would form the foundation for the content of the BEL.

Including Neufert's unpublished 'Lebensgestaltungslehre' in this issue on handbooks might help to frame handbooks as part of larger processes and projects. If a manual is not a stand-alone work, but part of a larger body of work (not bound to books), our understanding of a manual's intentions and effects necessarily shifts scales. The declared message (or audience) of such a handbook changes if one zooms out to include related works, transcending the distinctions of medium, edition or format altogether. Seemingly clearcut handbooks might suddenly seem closer to a different genre; conversely, notes jotted down in a diary can become a manual in their own right. After all, what is the material and methodological condition that actually makes a manual if what constitutes Neufert's Lehren were not the distributed books? Rather than an embossed title on the spine of a finished volume, they share a methodological and material procedure: they all consist of a series of DIN A formatted sheets collected in books, bureaucratic brochures or indexed diary entries, all subject to Neufert's formatting and sorting process.

Containing structures of different sizes each on a single sheet, Neufert subjected household tasks, buildings, diary entries or small objects to the same process. Overcoming the boundaries of scale, these equalized depictions within their normed frames could now be grasped across their former categorical differences - sorted into the system of Neufert's Lehre. All three of the Lehren are attempts to order the world, be it built, designed or imagined. Through first dividing this world into parts, formatting them and categorizing them, Neufert's Lehren were meant to enable the reader to then construct a new, normconforming world from these parts.

Hence, this is not a story of a handbook. Rather, by tracing the scattered remains of the 'Lebensgestaltungslehre' across their medial states I hope to unveil the power of a projective title (after all, calling it Lehre might already make it so), the scalar diversity of a decades-long formatting process, and their usefulness to the politics of their time. In fact, this essay posits that what produced Neufert's Lehren (both published and not) was the very act of formatting itself: of paper, of architecture and of subjects.

\section{One Lehre to teach them all}

When Neufert published the BEL, both teaching guides and reference works had a longstanding tradition in the discipline of modern Western architecture; in fact, the organized curriculum and guidebooks were part of the discipline's professional foundation. The thirty-three-volume Handbuch der Architektur, the BEL's most prominent (and extensive) predecessor, was launched in 1880, nine years after the founding of the new German empire. ${ }^{15}$ In the wake of industrialization, higher architectural education evolved in the nineteenth century from a 'school of style' to a 'school of method'. ${ }^{16}$ Additionally, as architecture historian Susanne Jany notes, modernization of German industries had produced new programmes, and the "novel types of buildings, such as railway stations, department stores, and disinfection plants, presented architects with the pressing question of how to design them appropriately to their purposes'. ${ }^{17}$ Rapidly evolving (and

Anstey, Katja Grillner and Rolf Hughes (eds.), Architecture and Authorship, London: Black Dog Publishing, 2007, pp. 148-55.

15 See Gernot Weckherlin's chapter on the history of handbooks in architecture in Weckherlin, op. cit. (2), pp. 74-82.

16 Ulrich Pfammatter, The Making of the Modern Architect and Engineer: The Origins and Development of a Scientific and Industrially Oriented Education, Boston: Birkhauser-Publishers for Architecture, 2000, p. 10.

17 Susanne Jany, “'Handbuch der Architektur” (1880-1943): a German design manual for the building profession' (2 June 2018), Historyofknowledge.Net, at https://historyofknowledge.net/2018/06/02/handbuch-der-architektur. 
changing) industrial standards and production processes additionally required up-to-date knowledge and information. And in true modern spirit, this prompted the attempt at a comprehensive system of rules and values - concisely printed on paper.

Books such as the Handbuch der Architektur were written not only to instruct students, but as a guidebook for the building of a new nation. In the late 1930s and early 1940s when Neufert published his BEL and BOL (in 1936 and 1943 respectively), architecture had become not just a series of monuments for the Third Reich, but a methodological strategy across scales. At the same time, industrialized production surged during wartime, and several attempts to fuse the diverse manufacturers' catalogues into a compendium for practising architects, as theorist and historian Gernot Weckherlin describes, were published during these two decades. ${ }^{18}$ Historian Anson Rabinbach has studied the aesthetic measures and manipulations of the National Socialist regime in their political context, detecting a marked shift in the perception and practice of design in the 1930s from the völkisch rhetoric and aesthetic toward an embracing of technology as aesthetics. ${ }^{19}$ But this was not a clean-cut succession of styles. As Paul Betts has astutely analysed in his book The Authority of Everyday Objects, there was 'no clear divide between 1932 and 1933 in German industrial aesthetics. Nazism provided little design innovation, nor did it ever really break from Weimar modernism' ${ }^{20}$ Historian Winfried Nerdinger links the 'eclectic' aesthetic concept of the 1930s and 1940s to the closing of the Bauhaus in 1933 and the dissolution of the Werkbund in 1938, with the modernist aesthetic being absorbed into the larger National Socialist toolkit. ${ }^{21}$ So what was it that Neufert aimed to teach through his manuals? Rather than contribute to a (mostly fictional) National Socialist aesthetic of the 'sacred or the aesthetic sublime', ${ }^{22}$ Neufert worked toward a normalization of political ideology by concretely shaping the design process - and ultimately the designer himself. Neufert's expertise as modernist, norm specialist and bureaucrat uniquely qualified him to shape Germany's new national landscape: a design task beyond the built.

In order to model National Socialist Germany into an economic super-force fuelling a nationalist-racist agenda demonstrating aesthetic, military and technological superiority, merchants under the stewardship of the government soon took to shaping and redesigning the means of the nation's production and people's everyday surroundings. The strategy was conceived by and carried out under the auspices of the architect and technocrat Speer. While the architect-bureaucrat had a long-standing history in German administration, rarely had an architect risen to such political prominence as Speer during his tenure under Hitler. ${ }^{23}$ He conceived of the National Socialist organization on several scales: he was instrumental to Germany's Gestaltung as Third Reich. In his function as 'inspector general of buildings' (Generalbauinspektor, GBI), Speer gave shape to the regime's fantasies of dominance with his plans for the reconstruction of Berlin as 'Germania', the Reich's

18 Gernot Weckherlin, “This book is not literature; it is a practical manual ...”: Diskursive und nicht-diskursive Praktiken in der Architektur', Thesis: Wissenschaftliche Zeitschrift der Bauhaus-Universität Weimar (2003) 4, pp. 46-58, 55.

19 Anson G. Rabinbach, 'The aesthetics of production in the Third Reich', Journal of Contemporary History (1976) 11(4), pp. 43-74.

20 Paul Betts, The Authority of Everyday Objects: A Cultural History of West German Industrial Design, Berkeley: University of California Press, 2004, p. 71.

21 Winfried Nerdinger, Bauhaus-Moderne im Nationalsozialismus: Zwischen Anbiederung und Verfolgung, Munich: Prestel, 1993.

22 Anson Rabinbach, 'The aftermath: reflections on the culture and ideology of National Socialism', in Peter Eli Gordon and John McCormick, Weimar Thought: A Contested Legacy, Princeton, NJ: Princeton University Press, 2013, pp. 394-406, 403.

23 Martin Kitchen's biography of Albert Speer is the first attempt at a critical political biography after Joachim Fest's ghostwritten account, which long remained the main reference. Joachim Fest, Speer: Eine Biographie, Berlin: Fest, 1999; Martin Kitchen, Speer: Hitler's Architect, New Haven, CT: Yale University Press, 2015. 
capital, or the oversight of the designs for the 1936 Olympic Games in Berlin by architect Werner March. As director of Organisation Todt (OT), a paramilitary building organization active mostly in the occupied territories, he oversaw the building of bunkers and defense structures from 1940. Despite being 'neither a technician nor a specialist', ${ }^{24}$ the architect Speer became minister of armaments in 1942, and from there on organized not just the military's weaponry, but the very state apparatus of the National Socialist regime itself. It was under Speer's superintendence that Neufert was called in to become the regime's norm expert in 1938. This involvement went beyond the transmission of aesthetic skills or technological know-how: in their official capacities, the bureaucrat-architects created systems and organizational principles for the ordering of space, territory, industry and the military - they designed a new state altogether.

In late 1943, Speer founded a new 'Arbeitsstab for the reconstruction of cities destroyed by bombing', planning the reconstruction of war damage even before the war had ended. Neufert was part of this Arbeitsstab, responsible for questions of 'systematic standardization'. At a meeting in April 1944, the members of the committee argued about the best way to produce mass housing after the war, stressing the importance of standardization and 'the right measure' for this process. ${ }^{25}$ At the next meeting in October, after Neufert presented his work on typologies and norms, Walter Groß (head of the Office of Racial Policy) declared questions of housing typologies as tools for 'racial selection'. ${ }^{26}$

Despite such direct involvement in terms of his employment, as well as discussed content, in his diary Neufert almost completely avoids commentary on political events. In October 1945, shortly after the end of the war, he writes, 'The work is going forward, but without great inspiration [Gedankenflug], and, additionally, joyful, unencumbered atmosphere is lacking, which, given the political events, does not even emerge here in the US occupied zone. ${ }^{27}$

One must wonder about Neufert's perceived lack of unencumbered atmosphere after Germany's liberation; but rather than explain, Neufert quickly continues with a retreat behind his facade of neutrality:

I keep my distance from these events as much as I can, but even with the smallest of connections with which one is connected to the economic life [Wirtschaftsleben] one feels the burden, which strains me above all measure given my especially sensitive, almost anxious constitution. ${ }^{28}$

Neufert had kept this 'distance from these events' (meaning the end of the Second World War) mostly rhetorically throughout his career; maintaining this sentiment afforded him liberation from many burdens (though not, first and foremost, the one mentioned here). By working directly for the National Socialist regime, this 'distance' most of all alleviated any burden of political accountability in the de-Nazification processes, allowing Neufert to

24 Kitchen, op. cit. (23), p. 12.

25 See the chapter on the history of the Arbeitsstab in Werner Durth and Niels Gutschow, Träume in Trümmern: Planungen zum Wiederaufbau zerstörter Städte im westen Deutschlands, 1940-1950, Braunschweig: Friedr. Vieweg \& Sohn, 1988, pp. 55-118.

26 Durth and Gutschow, op. cit. (25), pp. 77-8.

27 Neufert diary entry, 7 October 1945, Archiv der Moderne, Bauhaus-Universität Weimar: 'Die Arbeit selbst [geht] vorwärts, großer Gedankenflug stellt sich nicht ein dazu fehlt die freudige unbedrückte Atmosphäre, die durch die politischen Ereignisse selbst hier in der amerik. Zone nicht aufkommt.'

28 Neufert diary entry, 7 October 1945, Archiv der Moderne, Bauhaus-Universität Weimar: 'Ich halte mich soweit ich kann aus diesen Ereignissen heraus aber mit den kleinsten Bindungen mit denen man im Wirtschaftsleben steht spürt man diese Last, die bei meiner ja besonders empfindsamen fast ängstlichen Constitution über alle Maßen belastet.' 
seamlessly continue his career from the Arbeitsstab during the war to TU Darmstadt, where he was hired in 1946 as chair for 'design and standardization [Normung] in the building industry and urban planning, ${ }^{29}$ Keeping distance was Neufert's strategy to keep working on his Gestaltungslehre, which he turns to in the same diary entry only a few sentences later, asking, 'What is this work, this Gestaltungslehre? A search for the eternal laws, the rules of architecture'. ${ }^{30}$

\section{'Lebensgestaltungslehre': formatting total aesthetics}

In November 1936, Neufert mapped out in his diary a larger scheme for his books: a tripartite oeuvre as strategy toward a system of total organization. ${ }^{31}$ His BEL, published the same year, would provide pre-formatted elements for architectural design, and the 'Baugestaltungslehre' (a construction manual, which was also never published) would be the third step. Lodged between the two, Neufert proposed the 'Lebensgestaltungslehre' to provide the 'human foundations' ('menschliche Grundlagen') for the 'organization of life'. In another list of manuals a few years later in 1942, the BEL was followed by the BOL, with the 'Lebensgestaltungslehre' (abbreviated LG) as the last, final project on the list (Figure 3). ${ }^{32}$

Where the National Socialists 'untiringly glorified German labourers and labour' by using terms like Gestaltung, Neufert departed from the term's previous understanding as 'form-generating activity' and organic process toward Gestaltung as highly strategized acts of formatting and fitting. ${ }^{33}$ In Neufert's diary, the 'Lebensgestaltungslehre' was defined as 'explication of a successful technique for living, ${ }^{34}$ and contained filings ranging from musings on Nietzsche and Schopenhauer to the recurring Selbsteinreden. With those 'self-suggestions' (or rather, instructions), Neufert tried repeatedly to structure his day to save time and enhance his productivity. In an entry in 1936 he tells himself, 'Every morning from 5 to 8 except Tuesday and Thursday clean up; every evening from 6 to 9 in the public library except Wednesday and Saturday'. In August 1942, he reminds himself under bullet point 2 of a long list to 'practise his imagination' and under the next point to 'speak as little as possible' and 'never from excitement or anger'. Rising early was an obsession; so was sleep, as 'most often, yes, indeed generally such days were preceded by a bad night, or by an evening with alcohol and smoking, which brought the nerves in disarray'. ${ }^{35}$ For Neufert, the 'Lebensgestaltungslehre' was part of a 'vertical enterprise of the spiritual leadership in the building industry'; ${ }^{36}$ as 'every day has its scaffolding', so, too, every architect needed to 'think things through' and adopt a standardized daily rhythm. ${ }^{37}$ To shape life into order, sleep needed to be regulated just like working hours or floor plans.

29 'Lehrstuhl für Entwerfen, Normung im Bauwesen und Städtebau'. Ernst Neufert Archiv, TU Darmstadt.

30 Neufert diary entry, 7 October 1945, Archiv der Moderne, Bauhaus-Universität Weimar: 'Was ist diese Arbeit, diese Gestaltungslehre? Eine Suche nach den ewigen Gesetzen, den Spielregeln der Baukunst.'

31 Neufert diary entry 1936, Neufert papers, Archiv der Moderne, Bauhaus-Universität Weimar.

32 Neufert diary entry 1942, Neufert papers, Archiv der Moderne, Bauhaus-Universität Weimar.

33 Detlef Mertins identified Gestaltung as emerging in the 1920s as 'at once form, formation, form creation, and configuration - verb as well as noun, process as well as product, force as well as form. Gestaltung was the form-generating activity of all living being as well and of life itself. Mertins points out that even '[Curt Walter] Behrendt, like many of his contemporaries, looked to metaphors of nature and organic processes as regulative principles' for 'a new state of organicity'. Detlef Mertins, 'Introduction', in Walter Curt Behrendt and Detlef Mertins, The Victory of the New Building Style (tr. Harry Francis Mallgrave), Los Angeles, CA: Getty Research Institute, 2000, pp. 1-84, 30, 44.

34 Ernst Neufert diary, part of a bundle dated 20 November 1936, with remarks from 1980, Neufert papers, Archiv der Moderne, Bauhaus-Universität Weimar: 'Darlegung einer erfolgreichen Lebenstechnik.'

35 Neufert diary entry, 17 March 1947, Neufert papers, Archiv der Moderne, Bauhaus-Universität Weimar.

36 Neufert diary entry, 30 July 1944, Neufert papers, Archiv der Moderne, Bauhaus-Universität Weimar: 'Ein Vertikalkonzern der geistigen Führung im Bauen.'

37 Neufert diary entry, 17 March 1947, Neufert papers, Archiv der Moderne, Bauhaus-Universität Weimar: 'Jeder Tag hat sein Gerüst.' 


\section{Hiddeusec $15 / 8,42$}

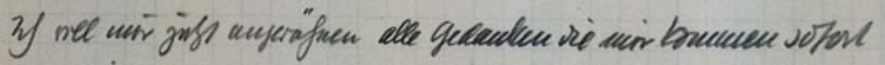

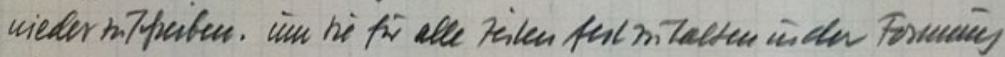

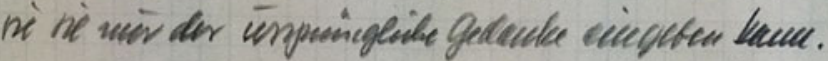

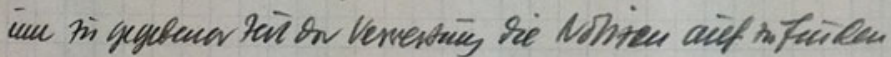

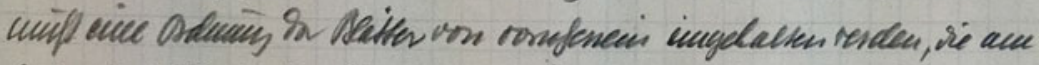

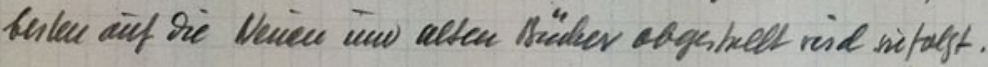

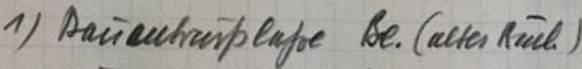

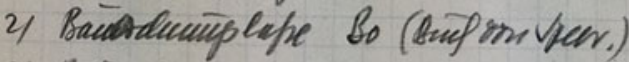

3) Baielafre Ba (Buif las ttralion)

4) Mreter fal das bor Ni ( Jear biaf

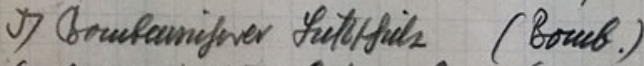

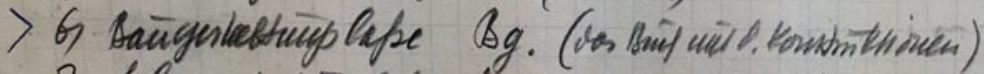

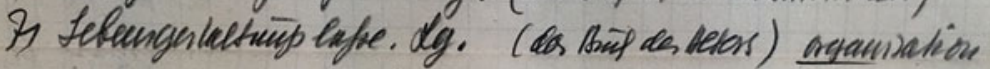

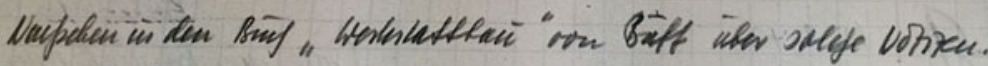

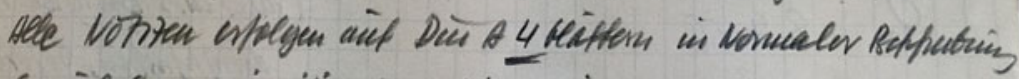

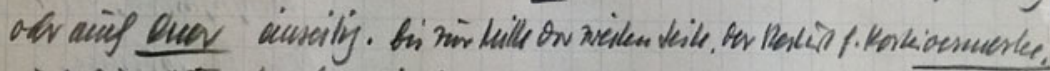

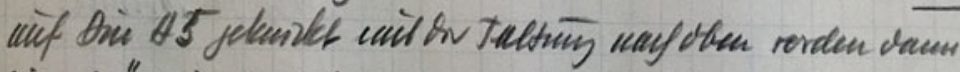

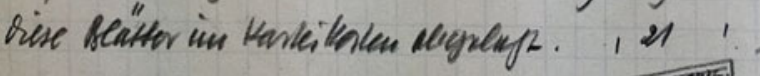
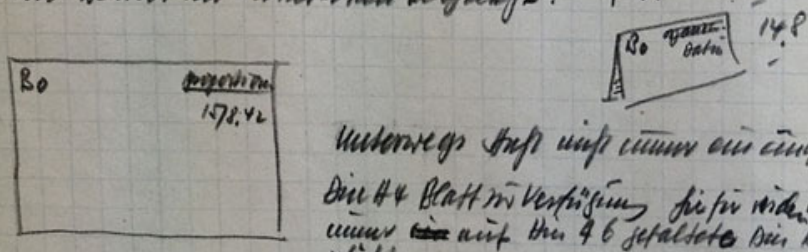

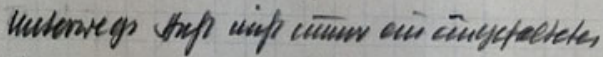

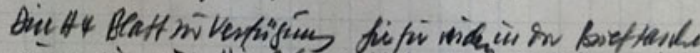

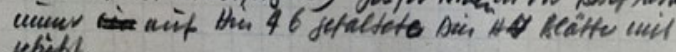
selistl.

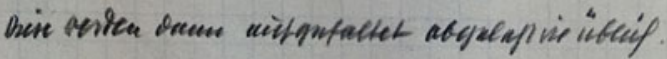

Figure 3. Neufert's planned book projects including the 'Lebensgestaltungslehre' and folding technique of DIN A sheets for future diary entries. Diary entry, 15 August 1942, Archiv der Moderne, Bauhaus-Universität Weimar.

The term Lebensgestaltung was not Neufert's invention. According to Peter Galison's analysis, philosophers such as Ludwig Wittgenstein and Otto Neurath were looking for a logical design for modern life that they called Lebensgestaltung as well, for which they deemed the modern architect to be the ideally fitted person, and the architects of the 
Bauhaus took their philosophical cues to understand the physical world as one built from elemental parts. ${ }^{38}$ But where Galison's analysis stresses the logic of modernism as one of constructivist assembly, Neufert's approach was one of divisibility as technique across scales. ${ }^{39}$ For Galison, Teilbarkeit then became the precursor to a systematic reconstruction of modernity, with both enterprises (logical positivism in philosophy and the Bauhaus in architecture) trying to instantiate a ... manifest building up from simple elements to all higher forms that would, by virtue of the systematic constructional program itself, guarantee the exclusion of the decorative, mystical, or metaphysical'. ${ }^{40}$ While Galison identifies this mode of what he calls 'transparent construction' as the exclusion of the metaphysical both in modern architecture and in modern philosophy, Neufert's quest (and, earlier, that of the DIN) was one of legibility through delimitation, of ordering things through division, rather than aggregating them toward construction. In that sense, Neufert surpassed the project of the Viennese circle of the logical positivists: where they had aimed to construct complexity from parts, the DIN assumed the world to be already made of parts.

For Neufert, divisibility became the core technique to order and design, as well as the method to produce his books. However, the striving for an encyclopedic entirety in bound form accompanies his thinking. He criticizes the building norms of the DIN due to their lack of being thought of as a divisible system, and rather being thought of as parts:

Given that the building norm sheets are not available in bound form, but only as single sheets, often even in a very thorough compilation the newest, valid norm sheet is missing. The planner is then often annoyed and relinquishes the use of norms at large. This defeats the purpose of norm making. ${ }^{41}$

Neufert deemed necessary a superordinated system in which everything else had to fit; norming the joints and spaces between parts was no longer sufficient. This desire for a formatted life and an order of thought was for Neufert directly linked to the praxis of making; as practitioner, Neufert was looking for a technique for ordering, or rather for making order possible in the first place. To arrive at this order, he divided things, even thoughts, and reconnected them through a larger system: the diary index, or the octametric measure system.

Rather than an additive system, as his colleague and competitor Martin Mittag had proposed, ${ }^{42}$ Neufert advanced a series of measures derived from a division of ten metres (for example, 5, 2.5, 1.25, and 0.625 metres) as the best foundation for a comprehensive

38 See Peter Galison, 'Aufbau/Bauhaus: logical positivism and architectural modernism', Critical Inquiry (1 July 1990) 16(4), pp. 709-52, 710.

39 The understanding of the world as a composite of parts had its roots in eighteenth-century philosophy, and found its conceptual and aesthetic consequence in architecture almost as early. See Antoine Picon, 'Architecture, science and technology', in Peter Galison and Emily Thompson, eds., The Architecture of Science, Cambridge, MA: MIT Press, 1999, pp. 309-35.

40 See Galison, op. cit. (38). For a larger investigation of Teilbarkeit as inherent concept of standardization in architecture see the Meister, op. cit. (6), Chapter 2, 'Teilbarkeit circa 1922: outlining objects'.

41 Neufert, op. cit. (5), p. 10: 'Da die Baunormungsblätter im übrigen nicht in gebundener Form, sondern lediglich als Einzelblätter erhältlich sind, so fehlt oftmals in einer noch so sorgfältigen Zusammenstellung das neueste, gültige Normenblatt. Der Planende ist dann oft durch die verzögernde Sucharbeit verärgert und verzichtet meistens auf die Anwendung der Normen überhaupt. Damit ist der Zweck der Normung verfehlt.'

42 Neufert owned a copy of Mittag's book and made comments and corrections, specifically in the parts regarding the different preferences for number systems. See the annotated copy in the Ernst Neufert Archiv, TU Darmstadt. Martin Mittag, Untersuchungen zur Massordnung im Hochbau, Hanover: Vincentz, 1949. 
system to norm all parts of the building process. ${ }^{43}$ In a drawing for the second edition of the BOL, Neufert illustrated several division methods for circles, trying to demonstrate the superiority of the two principles: if one assumed a metric system and divided a circle with a thousand units in half, and again, and again, one would arrive at Neufert's measure for the octametric system. Even more so, Neufert added, " $625 \mathrm{~mm}$ is in relation to the meter like the "golden section" $5: 8$; and $2 \times 625 \mathrm{~mm}=1.25 \mathrm{~m}$ is the decisive measure of the series of halving of $10 \mathrm{~m}$ '.

Neufert had found his perfect system: one that merged the metric with the halving principle, and simultaneously offered the ultimate trope of aesthetic order - the golden section. ${ }^{45}$ The embedded principle of Teilbarkeit - divisibility through cutting in half was the main organizing principle throughout Neufert's three Lehren: the seminal Bau-Entwurfslehre, the Bauordnungslehre, and his unpublished 'Lebensgestaltungslehre'. Furnished with this tool, Neufert could now proceed to seamlessly link from brick to man, house to furniture, and work processes to paper sizes. ${ }^{46}$ In 1942 , Neufert's work on this topic was issued in a special print titled 'Building norms as totality' ('Baunormung als Ganzheit') based on his octametric system from three years earlier. ${ }^{47}$ Linking measures in the building process together with this modular system, the new 'totality' promised, according to Neufert, improvement not only in production, but in Gestaltung: furniture would fit into buildings, and buildings would fit into grids if built according to the octametric system, promising progress on all fronts. Simultaneously, his 'Lebensgestaltungslehre', a book-to-be dispersed onto the folded DIN A4 sheets in the diary, took on material shape beyond social norms.

\section{Neufert's diary: a card index sorting life}

Though never realized as a book, the Lebensgestaltung is central to a larger understanding of Neufert's norm efforts. Beyond the creation of an encyclopedic kit of parts for architectural production (as in BEL), or a complete norm measure system for architecture (as in BOL), it was in his diary that Neufert developed instructions and formats as tools to design the very subject of life and how to live it. This diary, however, was neither a conventional journal nor a loose collection of thoughts, but a collection of index cards organized with abbreviations into different categories. The resulting card catalogue embodied the nineteenth-century technique seemingly promising the documentation

43 Walter Porstmann, author of the DIN A paper format, equally linked his norm formats to the system of the metre, which was deemed universal. Porstmann took this link from Ostwald, who had already married the Weltformat with the metre as dimension, albeit as a dimension of length, not area, which, according to Porstmann, made it an arbitrary and hence questionable connection. For the dispute between Ostwald and Porstmann over the authorship on the paper format see Markus Krajewski, Restlosigkeit: Weltprojekte um 1900, Frankfurt am Main: Fischer, 2006, pp. 64-140.

44 See correction drawings for the second edition of the BOL, Ernst Neufert Archiv, TU Darmstadt: ' $625 \mathrm{~mm}$ aber steht zum Meter im Verhältnis des Goldenen Schnitts 5:8; und $2 \times 625 \mathrm{~mm}=1.25 \mathrm{~m}$ ist ein entscheidendes Maß der Halbierungsreihe von $10 \mathrm{~m}$ '.

45 The perfection and application of the golden section as ultimate proof of the 'beauty' of rational scientific architecture preoccupied many of Neufert's contemporaries, for example Rudolf Wittkower, Architectural Principles in the Age of Humanism, London: The Warburg Institute, 1949. A proponent of its importance for modern architecture was, for example, Serbian French architecture theorist Miloutine Borissavliévitch, Le nombre d'or et l'esthétique scientifique de l'architecture, Paris, published by the author, 1952.

46 See, for example, the diagram called 'Hausgliederung' in the BEL, where Neufert divides the functions of domestic life into a series of abstract modules, allowing the architect to plan any house 'von der Einraumwohnung bis zum Schloss' ('from one-room apartment to castle'). Neufert, op. cit. (1), BauEntwurfslehre, p. 89.

47 Ernst Neufert, Baunormung als Ganzheit, Berlin: Elsner, 1942, p. 7. 
and production of universal knowledge. ${ }^{48}$ Filed according to a sophisticated system of abbreviated categories, Neufert catalogued all entries just like he catalogued student work - and how he would finally catalogue architectural parts in the BEL. The abbreviations corresponded with architectural typologies and categories in his books, turning the diary into a materialization of its own logic: an index that would produce manuals not just for architecture, but for Lebensgestaltung.

Neufert had organized his index so that he could record his thoughts 'immediately' to preserve them in the formulation, which 'only the original thought' provided. ${ }^{49}$ By filing them, he imposed order, turning them into documents to 'hold on to them for all times'. ${ }^{50}$ What constituted such thought was as diverse as his architectural scales, ranging from brick to city: they could be excerpts from Reader's Digest editions or a quote by Nietzsche followed by a series of time slots for lunch, coffee and nap on a workday. They did not need to be original, as long as they were formatted correctly in the diary sheet system. Thus transformed into carriers of recorded information, the diary sheets became part of a catalogue system, and were maintained, updated and corrected accordingly. ${ }^{51}$ Most of the sorted entries are from the late 1930s and the early 1940s, with annotations into the 1980s. Also labelled 'diaries' (dated with the years 1944 to 1947), Neufert later used a stack of pre-printed calendar forms, with a week on each page in A6 format; whether those were sorted into the index remains unclear, but they contain scheduling entries such as meetings with collaborators or professional travel, and are less a record of the 'original thought' as he instructed himself with regard to the index entries. As sheets in an index they became sortable, storable and interconnected, a tool to order existing ideas and generate new ones. Hence it was Neufert's index diary that remained an active format for decades, as commentaries and additions reaching into the 1980s demonstrate.

Neufert's reliance on formatting was a question both of index and of the format of the indexed files; the most successful DIN norm to date in terms of breadth of application and international export, the DIN A series, had a profound impact on Neufert's work. It was authored by Walter Porstmann (a former assistant to Wilhelm Ostwald, who had been the creator of the 'world format'), and Neufert conversed with him about norms and their respective publications well into the $1940 \mathrm{~s}^{52}$ Porstmann, a mathematician, had defined the format through theorems and a process of division. The so-called 'halving theorem' (Halbierungssatz), together with the 'similarity theorem' (Ähnlichkeitssatz) derived each smaller format in the series by dividing the next-larger one in half, ensuring their geometrical similarity. This division was rooted in a material manipulation rather than abstract measuring: divisibility in Porstmann's scheme was 'not a random half ...

48 For a historical and theorectical treatment of the card index see Markus Krajewski, Zettelwirtschaft: Die Geburt der Kartei aus dem Geiste der Bibliothek, Berlin: Kulturverlag Kadmos, 2002.

49 Neufert diary entry, 20 November 1936, Neufert papers, Archiv der Moderne, Bauhaus-Universität Weimar.

50 Neufert diary entry, 15 August 1942, Neufert papers, Archiv der Moderne, Bauhaus-Universität Weimar: 'Ich will mir zuerst angewöhnen alle Gedanken die mir kommen sofort niederzuschreiben, um sie für alle Zeiten festzuhalten in der Formung wie sie nur der ursprüngliche Gedanke eingeben kann'.

51 Many of the diary entries bear several dates, usually in different types of pen in order to link the changes or notes on the inside of the folded sheet to the respective date on the outside.

52 The DIN 476 that defined the DIN A series was authored by Porstmann and published in 1922. For the theoretical foundation of his own work see Walter Porstmann, Papierformate: Im Auftrag des Normenausschusses der Deutschen Industrie, Dinbuch 1, Berlin, 1922. For a political history of the paper format in Neufert's work see Nader Vossoughian, 'From A4 paper to the octametric brick: Ernst Neufert and the geo-politics of standardisation in Nazi Germany', Journal of Architecture (2015) 20(4), pp. 675-98. For a history of Porstmann and Ostwald see Krajewski, op. cit. (43), pp. 64-140. 
but that half which emerges through simply folding' the paper. ${ }^{53}$ The normed 'card index' with DIN 6-sized sheets was the model for Neufert's diary. ${ }^{54}$ Neufert not only used Porstmann's standard-sized paper sheets (A4) for his entries, but, rather than using readymade DIN A6 index cards used in standardized library indices, he turned them into his card index by folding them - applying Porstmann's theorem to the sheets manually. For the DIN, the card index had become tool and material for its own norm production. In an advertisement printed on the jacket of Dinbuch 8 on drawing norms, the DIN promotes its own 'Porstmann system': 'The DIN subscription card index is the connection between the producer and consumer of DIN norms. ${ }^{55}$

In Neufert's case, the card index materially connected author and his readership of one. The paper's size and categorization were the most consistent qualities of the papers in the diary: the sheets varied in colour (from white to brown to pink), sometimes were lined, sometimes consisted of ripped-out graph paper from a journal, but most often were blank. Yet unaffected by the printed structure or its time of origin, Neufert's handwriting remained uniform across the pages. Writing in fountain pen with varying colours of ink, he sometimes switched to pencil, and made accompanying sketches (of a building he saw in a dream, furniture details or his paper-folding technique) with the same tool. Reworking the entries time and again, he layered inks, lead and insights onto the normed sheets, becoming author and editor, commentator and subject.

Neufert also used A4 as a format for his books. While the BEL was in DIN A4 format, the first edition of the BOL 'sadly could not be a DIN format as it needs to comply with the format of the publications by Speer's ministry'. ${ }^{56}$ Part of the work for the second edition (1961) consisted of the reformatting of the content onto the normed paper format. Furthermore, the paper became the medium to bridge scales, to connect architect and architecture - materially and literally. Where the paper format was 'normed', a norm-sized binder followed. As both a normed object and a carrier of further norms, the two-dimensional sheet of paper was represented graphically as surrounded by an ever-expanding entourage (Gefolge) capable of formatting space. Soon after came the norm for the filing cabinet, and lastly the building that housed this normed furniture. That building, in turn, was built from normed parts: the window, the door, the brick all were defined by DIN norms. Neufert accordingly planned office buildings around paper-stack dimensions, promoted furniture suitable to roll out DIN A0 plans, ${ }^{57}$ and repeatedly based his measure system on the paper format series.

By taking both the nineteenth-century idea of the card index as producer of universal knowledge and the DIN's understanding of paper format as materialized system in and of itself, Neufert used formatted paper to slice and slot life design onto its sheets. The filing

53 Walter Porstmann, Normenlehre, Leipzig: Schulwissenschaftlicher Verlag A. Haase, 1917, p. 212: 'Und zwar nicht eine beliebige Hälfte ... sondern die Hälfte, die durch einfaches Zusammenfalten des größeren Formats entsteht.'

54 For a history of the Kartei (card index) as tool toward knowledge creation see Markus Krajewski, Paper Machines: About Cards \& Catalogs, 1548-1929, Cambridge, MA: MIT Press, 2011.

55 Advertisement on the inside of the jacket of Adolf Heilandt, Zeichnungsnormen, Dinbuch 8, Berlin, 1924: 'Die DIN-Bestellkartei ist die Verbindung zwischen Lieferer und Verbraucher von Dinormen.'

56 Preface to BOL (1943): 'Das Format des Buches konnte leider kein DIN-Format sein, da es sich der Buchreihe des GBl einordnen mußte.' And still, in 1961, he explains, 'The already prepared new edition in DIN A4 format was lost through the detrimental effects of the war' ('Die vorbereitete Neuauflage im DIN A4 Format ging mit allen Unterlagen durch Kriegseinwirkungen verloren'). See Ernst Neufert, 'Vorwort', in Bauordnungslehre, 2nd edn, Frankfurt am Main and Berlin: Ullstein Verlag, 1961, annotated by Neufert with corrections for the 3rd edn, Ernst Neufert Archive, TU Darmstadt.

57 See, for example, the desk used by his students at the Bauhochschule Weimar where Neufert taught in the late 1920s, which was almost identically depicted in the BEL, in Werner Gräff, ed., Staatliche Bauhochschule Weimar, 1929, Weimar: Verlag Staatliche Bauhochschule, 1929. See also Neufert's repeated reference to DIN A formats in the 'Bauwelt-Tafeln' inserted in Bauwelt, 1935, the BEL and the BOL. 
system and the size of the folded sheets provided a superordinated system to unify diverse thoughts and scales - an apparatus for Lebensgestaltung.

\section{The technique of Teilbarkeit}

In the late 1930s, in the wake of the BEL's success and while writing the BOL, Neufert used terms such as 'naturally' (naturgemäß) and 'nature' (Natur) to introduce and justify his instructions, already found in the BEL, even more frequently. ${ }^{58}$ For Neufert, invoking 'nature' served a double purpose: on the one hand he used it to naturalize 'found' norm measures for his octametric system and building materials and objects 'naturally' matching up with it, justifying the location of windows between columns or the measures of swimming pools; on the other, nature itself became part of ordered and normed life.

Neufert's idea of 'organic life' was based on rigorous discipline toward the body and toward the mind. His constant and repeated entries titled 'life plan' (Lebensplan) or 'selfsuggestion' (Selbsteinrede) map out a life devoted to work. Annemarie Jaeggi called Neufert's obsessions toward disciplining spaces and bodies into his norm measures a 'compulsive act', and the diary entries seem to confirm such an assessment. ${ }^{59}$ And yet a certain yearning for a discipline that would come naturally, that might not require the constant Selbsteinrede and guilt that would come with it, seems to seep through the rationalized visions of farm living in his diary. In Neufert's 'Lebensgestaltungslehre', time, behaviour and work projects were all sorted and divided into functional snippets toward higher productivity. The saving of energy that official bodies demanded of the population, Neufert expected of the designer. As equal project next to the building norms and the building manual toward the making of efficient, economic objects, he aimed to construct a designing subject with the same qualities.

In multiple diary entries in the 1940s, Neufert painted a structured life in peacetime: a whole village planned according to the octametric system, following his instructions on orderly conduct. In 1947, he envisioned people living on a farm together, with a clubhouse to host friends, a library and a bookshop organized according to the latest developments in card-index logistics, Sunday trips in the car and a communal kitchen during the week. But this was not an escapist idyll to get away from all things after the war; neither does he picture the group as a social community or family. What he portrays is an Arbeitsstab, using the terminology of Speer's organization in the ministries. ${ }^{60}$ On Neufert's farm, men would order nature, not revel in it. Testing (and living out) his ideas for agrarian buildings and systems, Neufert's ambitions went beyond the mere cataloguing of dog kennels or feeding trays for cows. He paints a scene of modernized nature, where 'everything [was to be done] with clear, precise attitude. Naturally organic and yet modern' ${ }^{61}$ Nature, as Neufert defines it in his diary, 'must be created in its precision, both in the part as in the whole'; in fact, he declaims, 'reason, creator of nature!' ${ }^{62}$ Just like the human subject,

58 Neufert, op. cit. (5), pp. 37, 73, 106, 142, 148, 244, 283, 364, 372, 375, 427.

59 Jaeggi phrased this in a paper given at the Ernst Neufert Symposium at the Bauhaus University in Weimar, April 2014.

60 Neufert's vision of the Arbeitsstab forms the link between the Nazi ideology of nature and the obsession of norm and the transgression of scales. Neufert diary entry, 30 July 1944, Neufert papers, Archiv der Moderne, Bauhaus-Universität Weimar: 'Ich denke deshalb daran einen Teil meines Arbeitsstabes ... auf ein Mustergut zu legen daß [sic] ich selbst aufbaue.'

61 Neufert diary entry, 30 July 1944, Neufert papers, Archiv der Moderne, Bauhaus-Universität Weimar: 'Alles in einer klaren Haltung. Naturhaft organisch und doch modern.'

62 Neufert diary entry, 1947, Neufert papers, Archiv der Moderne, Bauhaus-Universität Weimar: 'Kant: So muß die Natur in ihrer Bestimmtheit im einzelnen wie im Ganzen erst geschaffen werden. Der Verstand, Urheber der Natur!' 
nature for Neufert was the result of Gestaltung. Despite the justification rhetoric, it was not nature that gave order to the form. Rather, reason needed to order nature, subsuming it under the total system, or rather parcel it out and slot it into the grid - both literally and figuratively.

For Neufert, books and diary were not just part of such order, but both were created and organized through the mechanics of the card index. In his BOL, Neufert argues for the principle of halvability by showing a plan of a Palladio villa, pointing out the sequence of spaces sequentially halved in proportion and surface area, producing the perfect system for 'good architecture'. ${ }^{63}$ He also applauds Palladio's 'rigour' in the implementation of this principle. The halving of spaces together with their rearrangement produces, according to Neufert, exemplary architecture. A page earlier in the BOL, Neufert calls this cutting in half a 'natural instinct' (with his usual strategy of naturalizing the origins of his norms by long histories as Urtriebe):

The continued cutting in half is the most primitive, most obvious and simplest form to divide things. Even the little child starts while playing with paper to halve the sheet, then further halves the half and so forth. Every adult halves their letter sheets in continued sequence out of a natural play instinct. ${ }^{64}$

This halving of sheets that Neufert explains as instinct here was at the same time the technique he lays out in his diary - for the diary itself. In one of his entries, Neufert specified (to himself), 'all notes will be made on DIN A4 sheets ... but only halfway up on the reverse page. The rest [of the page] is for Karteinotizen, folded to DIN A5 with the fold oriented upwards'. This instruction was followed even when travelling, where Neufert planned to always carry a stack of folded sheets (hence formatted from A4 to A5). Those were then 'be filed as usual' in the index card box that formed his diary: 'In order to allow for their future use, the sheets must be kept in a specific order from the very beginning; this order will be best based on the new and old books as follows'. ${ }^{65}$

The principle of division, or rather halving, was not limited to measures or floor plans, or to the diary itself. In 1942, one year before the Bauordnungslehre was published, Ernst Neufert wrote one of his so-called 'self-suggestions' (Selbsteinreden). The list of resolutions, which Neufert regularly composed to instruct himself toward a better, more ordered life, was headed by the following instruction: '1) to consider everything in a mode of accurate dissection [genau zergliedernd betrachten], and if necessary, to imprint it on the memory in such a way that it remains' ${ }^{66}$

He then moved on to a more general reminder - '5) to divide, order everything' - and then went on to continue plans of how to format this life (i.e. to speak as little as possible in order not to waste energy, to formulate precisely, etc.). ${ }^{67}$ One way to reach this goal was

63 Neufert, op. cit. (5), p. 24.

64 Neufert, op. cit. (5), p. 23.

65 Neufert diary entry, 15 August 1942, Neufert papers, Archiv der Moderne, Bauhaus-Universität Weimar: 'Um zu gegebener Zeit der Verwertung die Notizen aufzufinden muß eine Ordnung der Blätter von vornherein eingehalten werden, die am besten auf die Neuen [sic] und alten Bücher abgestellt wird wie folgt'.

66 Neufert diary entry, 15 August 1942, Neufert papers, Archiv der Moderne, Bauhaus-Universität Weimar: 'Alles genau zergliedernd betrachten und wenn nötig so in das Gedächtnis prägen das [sic] es sitzt.'

67 The imperative to save energy can be traced back to the Technikerbewegung of the nineteenth and early twentieth centuries on the one hand, and to Wilhelm Ostwald on the other. Waldemar Hellmich, the DIN's first director and engineer, and Walter Porstmann, who was Ostwald's assistant and the author of the DIN A series, certainly propagated this rhetoric and ideology into the DIN. Krajewski, op. cit. (43), pp. 64-140. 
to '10) write not a diary but a daily index, in which all thoughts of the day are collected in order' ${ }^{68}$

This desire for a formatted life and an order of thought was for Neufert directly linked to the praxis of making. And as practitioner in this sense, Neufert sought a technique for ordering - or rather, a technique that would make order possible in the first place.

\section{Man measured like all things}

In a world of Neufert's Lehren, the production of a manual followed the same method as the design of a house or taking notes of thoughts. The diary was not only the site to construct the 'Lebensgestaltungslehre' by compiling folded papers, but simultaneously where Neufert planned the dissection of the day into working slots for their production. Analogous to his calculations for standardized brickwork according to his measure system, where he would calculate wall lengths to then divide them by brick size to find out the required amount of material, Neufert planned a new book by taking the page count of his already written books, and the time spent by him or his co-workers on the book, producing a quotient for calculating the book yet to be written ${ }^{69}$. Not surprisingly, decades later Neufert noted on the diary sheet that the calculation had not produced the predicted result - the book remained unwritten.

And yet all of Neufert's Lehren continue to influence architectural practice. Students, practitioners and administrators used (and still use) the BEL, absorbing architectural standard solutions as unsuspecting neutral building blocks and grid systems into their designs. The BOL, shorter-lived and less widely distributed, was strategically important in the construction of a coherent norm system across architectural production (including bunkers). The 'Lebensgestaltungslehre' never had a shot at becoming a successful folio: it remained a loose series of paper sheets with a readership of one. And yet it was made following the same logic: a catalogued categorization of elements, made relatable through the application of the same system of division, categorization and systematization. The normed paper as common carrier (ideally in DIN A4) reinforced the material logic across all three works. In fact, one might argue that only some of his works ultimately took the form of a bound volume, while all of them existed in different loose-leaf states at one point. The medium of the diary itself - normed paper sheets sorted in an index - materialized as treatise for architectural order.

The unpublished 'Lebensgestaltungslehre' project resituates Neufert's published treatises, rendering their conventional reception as mere pragmatic tools untenable. So far absent from Neufert's historiographical treatment, this third Lehre foregrounds the scale of his aspirations - not in size, but in reach. Neufert expanded the notion of Lebensgestaltung from how it was understood around the turn of the century (for example among the logical positivists). By working on systems rather than on the shape and form of the finalized building or object, Neufert thought it possible to make every part conform - including the subjects inhabiting the building. For Neufert, his Lehre was not limited to objects or even architecture - all was subject to Gestaltung, most of all the human subject. Hence Neufert's books did not prescribe one distinct form for things, but presented a strategy for fitting designed parts into the larger (political and aesthetic) system. Beyond enabling the creation of an encyclopedic kit of parts for architectural production (as in $B E L$ ), or a complete system of norm measurements for architecture (as in BOL),

68 Neufert diary entry, 15 August 1942, Neufert papers, Archiv der Moderne, Bauhaus-Universität Weimar: '10) kein Tagebuch sondern eine Tageskartei schreiben in der all die Gedanken geordnet aufgeschrieben werden die so am Tage aufkreuzen'.

69 See the supplementary materials for a photograph of this diary page. 
dissecting the world into parts again and again ultimately became a tool for Neufert to format the very subject of life. Only when divided, ordered, sorted and compiled could floor plans be printed next to ironing boards, could notes about how to write be found next to musings on Kant or a sketch of the Leibnizhaus in Hanover. The index structure behind the Lehren allowed for ideological shuffling across categories.

And not just shuffling - Neufert's Lehren were concrete acts of shaping both built and social environments. The Third Reich's aesthetic representation followed a similar strategy as the regime's construction of an ideological apparatus which was in 'constant need of refinement and reinterpretation', as Anson Rabinbach pointed out. ${ }^{70}$ Where this ideological construct depended on the "willingness to adhere to the precepts of the [Nazi] worldview which was vague and indistinct enough to embrace a variety of related perspectives' ${ }^{71}$ the regime's shaping of people's everyday lives was continually, concretely materialized in regime-selected aesthetic forms and shaping of mass-produced objects. ${ }^{72}$ And while, in fact, the regime never had (despite later representations in the media) a uniform aesthetics, Neufert's trans-scalar measures, grids and design norms, following Speer's initiative, were attempts to normalize a new German nation. The actual 'large scale' of the National Socialist Gleichschaltung of German society became the making-same of the German subject itself.

For Neufert, man was never the measure of all things (although his use of the term, together with a Vitruvian vignette on book covers, publications and letterheads, abounds); rather, man needed to fit his system. ${ }^{73}$ In fact, man needed to be told how to fit the system: through Selbsteinreden, repeated rules for daily conduct or work ethic and the octametric system. Analysing his Lehren not as stand-alone volumes but as part of an approach to regulate life at large, Neufert's 'Lebensgestaltungslehre' undermines the technophile rhetoric of modern 'objectivity' and political and aesthetic 'neutrality' found in Neufert's own writing as well as his reception. The fragile materiality of his index diary betrays his seemingly robust technique of dividing objects, measures and thoughts alike to reformat them into one total system. Governed by his octametric system, there was no need for a relativized scale - there was no category that could not be filed in the index. Life became but one more area to be designed according to the octametric system - sorted under 'LG' for 'Lebensgestaltungslehre'. By dividing material, thought and objects into their parts, Neufert could think not only about a housebuilding machine or a brick, but about a systematically formatted subject. When Neufert crossed out the 'scale of the human' (Maßstab Mensch) for the second edition of the BOL to replace it with 'human building measures' (Menschliche Baumaße), he literally subordinated man to his total system of order. ${ }^{74}$

Neufert claimed throughout his career political neutrality for both himself and his work, precisely by defining his work on Norm as technical standards rather than societal conduct. And yet Neufert's Lehren were political tools, especially in an era in German history where representational strategies became a key political method across scales. Treating the 'Lebensgestaltungslehre' as third manual demonstrates Neufert's ease in applying material and abstract order to realms beyond conventional disciplinary and

70 Rabinbach, op. cit. (22), 395.

71 Rabinbach, op. cit. (22), 395.

72 Most explicitly this work was done through the Beauty of Labour initiative under Albert Speer, which selected exemplary and standardized objects and guidelines for factory workers and workers' housing, effectively designing the population's entire environment. See Chup Friemert, Produktionsästhetik im Faschismus: Das Amt 'Schönheit der Arbeit' von 1933 bis 1939, Munich: Damnitz, 1980; and Rabinbach, op. cit. (19), pp. 43-74.

73 The fact that women did not fit the system was not perceived as a real problem by Neufert. Gerd Kuhn, 'Die Spur der Steine: Norm-Ziegel, Oktametersystem und “Masztab Mensch”' in Prigge, op. cit. (8), pp. 335-57.

74 See the supplementary materials for a scan of the corrections. 
categoric bounds. By equally formatting his subject - human as well as architectural Neufert instructed both himself and future architects in how to break down the world until it fit into his grid. In Neufert's book, norming objects and formatting life were part of the same act.

Supplementary material. The supplementary material for this article, which is a file showing a further three pictures, can be found at https://doi.org/10.1017/bjt.2020.13.

Acknowledgements. I want to thank the reviewers for their comments and the editors of this issue for creating a wonderful group of people to think with; the Max Planck Institute for the History of Science, Berlin, for providing community as well as the funds necessary to live and work; the Ernst-Neufert-Stiftung and the Archiv der Moderne at the Bauhaus-Universität Weimar for for granting image permissions; and the latter for letting me investigate Ernst Neufert's diary in its original index-card state. All translations from German are mine, unless otherwise noted.

Cite this article: Meister A-M (2020). Ernst Neufert's 'Lebensgestaltungslehre': formatting life beyond the built. BJHS Themes 5, 167-185. https://doi.org/10.1017/bjt.2020.13 